\title{
Methane dynamics in different boreal lake types
}

\author{
S. Juutinen ${ }^{1, *}$, M. Rantakari ${ }^{2}$, P. Kortelainen ${ }^{2}$, J. T. Huttunen ${ }^{3, \dagger}$, T. Larmola ${ }^{1,{ }^{* *}}$, J. Alm ${ }^{4}$, J. Silvola ${ }^{1}$, and \\ P. J. Martikainen ${ }^{3}$ \\ ${ }^{1}$ Department of Biology, University of Joensuu, Finland \\ ${ }^{2}$ Finnish Environment Institute, Helsinki, Finland \\ ${ }^{3}$ Department of Environmental Sciences, University of Kuopio, Finland \\ ${ }^{4}$ Finnish Forest Research Institute, Joensuu Research Unit, Finland \\ *now at: Mount Holyoke College, Environmental Studies Program, USA \\ ** now at: Department of Forest Ecology, University of Helsinki, Finland \\ ${ }^{\dagger}$ Passed away during the course of the project
}

Received: 30 July 2008 - Published in Biogeosciences Discuss.: 1 September 2008

Revised: 6 January 2009 - Accepted: 23 January 2009 - Published: 16 February 2009

\begin{abstract}
This study explores the variability in concentrations of dissolved $\mathrm{CH}_{4}$ and annual flux estimates in the pelagic zone in a statistically defined sample of 207 lakes in Finland. The lakes were situated in the boreal zone, in an area where the mean annual air temperature ranges from -2.8 to $5.9^{\circ} \mathrm{C}$. We examined how lake $\mathrm{CH}_{4}$ dynamics related to regional lake types assessed according to the EU water framework directive. Ten lake types were defined on the basis of water chemistry, color, and size. Lakes were sampled for dissolved $\mathrm{CH}_{4}$ concentrations four times per year, at four different depths at the deepest point of each lake. We found that $\mathrm{CH}_{4}$ concentrations and fluxes to the atmosphere tended to be high in nutrient rich calcareous lakes, and that the shallow lakes had the greatest surface water concentrations. Methane concentration in the hypolimnion was related to oxygen and nutrient concentrations, and to lake depth or lake area. The surface water $\mathrm{CH}_{4}$ concentration was related to the depth or area of lake. Methane concentration close to the bottom can be viewed as proxy of lake status in terms of frequency of anoxia and nutrient levels. The mean pelagic $\mathrm{CH}_{4}$ release from randomly selected lakes was $49 \mathrm{mmol} \mathrm{m}^{-2} \mathrm{a}^{-1}$. The sum $\mathrm{CH}_{4}$ flux (storage and diffusion) correlated with lake depth, area and nutrient content, and $\mathrm{CH}_{4}$ release was greatest from the shallow nutrient rich and humic lakes. Our results support earlier lake studies regarding the regulating factors and also the magnitude of global emission estimate. These results propose that in bo-
\end{abstract}

Correspondence to: S. Juutinen (sjuutine@mtholyoke.edu) real region small lakes have higher $\mathrm{CH}_{4}$ fluxes per unit area than larger lakes, and that the small lakes have a disproportionate significance regarding to the $\mathrm{CH}_{4}$ release.

\section{Introduction}

With accumulating information, lakes have grown in significance as regional and global sources of atmospheric methane $\left(\mathrm{CH}_{4}\right)$. Most recent annual lake $\mathrm{CH}_{4}$ emission estimates are $8-48 \mathrm{Tg}$, i.e. $6-16 \%$ of the global natural $\mathrm{CH}_{4}$ emissions (Bastviken et al., 2004), and $24.2 \pm 10.5 \mathrm{Tg}$ (Walter et al., 2007). Saarnio et al. (2008) estimated that large lakes alone contribute to $24 \%$ of all wetland $\mathrm{CH}_{4}$ emissions in Europe. The current study contributes to the fact that small lakes may have proportionally high significance in element fluxes in the landscapes (see Cole et al., 2007). The smallest lakes are shown to have high sedimentation rates and large $\mathrm{CO}_{2}$ and $\mathrm{CH}_{4}$ emissions per unit area in samples of arctic, boreal and temperate lakes (Michmerhuizen et al., 1996; Kortelainen et al., 2000; Bastviken et al., 2004; Kortelainen et al., 2004 and 2006; Walter et al., 2007). Particularly small lakes in the areas of thawing permafrost form significant spot sources of atmospheric $\mathrm{CH}_{4}$ (Hamilton et al., 1994; Walter et al., 2007). The new estimates of number and area of global lakes emphasized the high number of small lakes in the boreal and arctic regions (Downing et al., 2006). These small water bodies are susceptible to ongoing changes in climate and land use, which may notably alter the lake environment and their $\mathrm{CH}_{4}$ fluxes. For example, increasing or decreasing lake areas as a consequence of shifts in water balance have

Published by Copernicus Publications on behalf of the European Geosciences Union. 


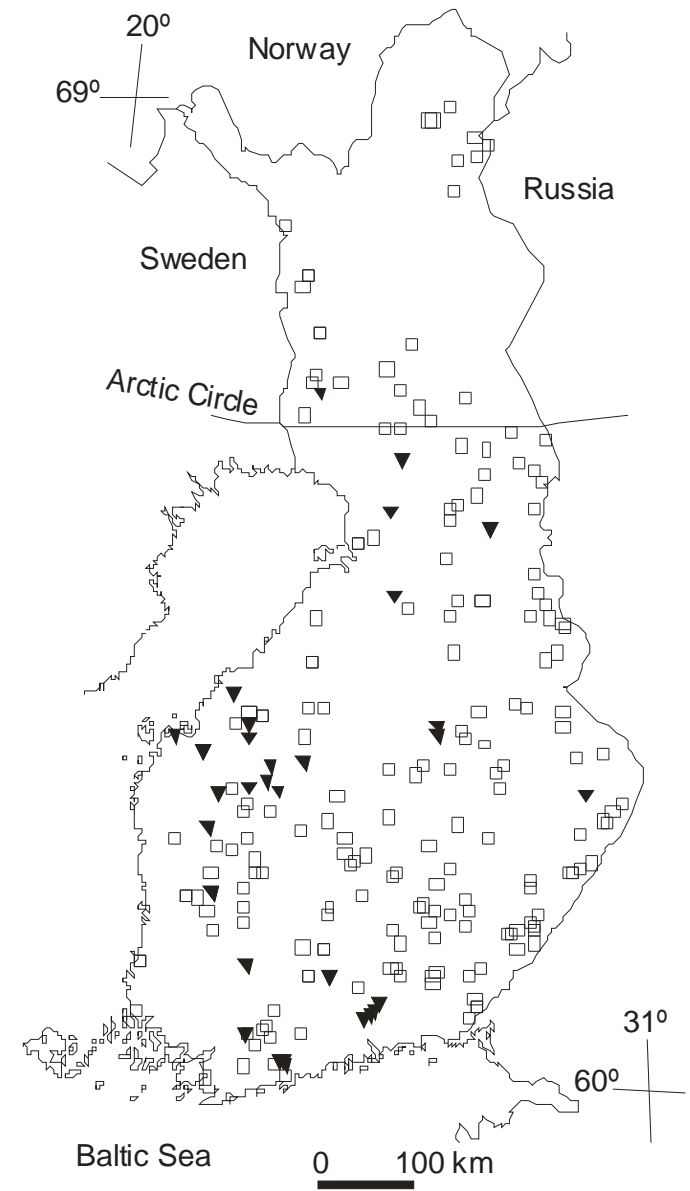

Fig. 1. Geographical distribution of the statistic sample of 177 lakes from Finnish Lake Survey data base (open symbols), and the additional sample of 30 lakes with the highest total phosphorous concentration (filled triangles).

been documented recently for northern lakes (e.g. Smith et al., 2005; Smol et al., 2007). In order to better understand the drivers behind the variability in the observed emissions, to reduce uncertainty in global estimates, and to estimate the anthropogenic influence on lake-derived $\mathrm{CH}_{4}$ emissions, comparison of $\mathrm{CH}_{4}$ dynamics and net emissions in different types of lakes is required.

The production of $\mathrm{CH}_{4}$ in freshwater lake sediments is a microbial process, mainly regulated by the presence of anoxia, temperature, and the amount and quality of substrates (Rudd and Hamilton, 1978; Strayer and Tiedje, 1978; Kelly and Chynoweth, 1981; Liikanen et al., 2003). Methane concentration in the water column, in turn, is affected by many biological and physical processes. A large proportion of $\mathrm{CH}_{4}$ produced in the sediment can be consumed at the sediment surface or in the water column by methanotrophs, a process that contributes to oxygen deficiency (e.g. Rudd and Hamilton, 1978; Bastviken et al., 2002; Liikanen et al., 2002; Kankaala et al., 2006). The retention of $\mathrm{CH}_{4}$ in the water column, the rate of gas transport and liberation of $\mathrm{CH}_{4}$ from the surface are determined by several factors: stratification and seasonal overturns of the water mass driven by temperature, wind forced mixing, diffusion along the concentration gradient, boundary layer dynamics, bubble formation and plant mediated transport (Dacey and Klug, 1979; Chanton et al., 1989; MacIntyre et al., 1995; Michmerhuizen et al., 1996; Bastviken et al., 2004; Bastviken et al., 2008). Generally, high micro- and macrophyte production rate, small water volume, and high organic carbon content all promote the formation of anoxic hypolimnion and are related to increased concentrations and fluxes of $\mathrm{CH}_{4}$ (Michmerhuizen et al., 1996; Riera et al., 1999; Huttunen et al., 2003; Bastviken et al., 2004; Kankaala et al., 2007).

Lake typology might provide a tool to deal with the physical and biological features of lake ecosystems, and to find a reasonable basis, for example, for estimation of $\mathrm{CH}_{4}$ fluxes. The European Union water framework directive (Directive 2000/60/EC) requires the Member States to typify lakes in order to recognize and improve the ecological status of lakes. The aim is to meet the natural status of the each lake type. Regional typologies are based on morphometry and water chemistry. Besides the European Union, an ecosystemspecific framework for nutrient criteria was recently presented in the North-America by Sorrano et al. (2008). This kind of approach could link the studies of the greenhouse gas methane to overall environmental monitoring of lakes.

We report the variability in dissolved $\mathrm{CH}_{4}$ concentrations and storage change and diffusive $\mathrm{CH}_{4}$ fluxes as derived from the concentrations in a statistically defined sample of 207 boreal lakes in Finland. The data are distributed according to regional lake typology (Vuori et al., 2006) based on simple water quality and morphometric measurements. We examine 1) a lake type as an indicator of the $\mathrm{CH}_{4}$ concentrations and fluxes, 2) quantitative relationships among $\mathrm{CH}_{4}$ concentrations and fluxes and water chemistry, morphological, and climatic variables, and 3) the relationship between the occurrence of anoxia, nutrient content and $\mathrm{CH}_{4}$ concentration. The same water samples have been analyzed for $\mathrm{CO}_{2}$ and those results were presented in Kortelainen et al. (2006).

\section{Materials and methods}

\subsection{Study lakes and lake typology}

Dissolved methane concentrations were examined from 207 Finnish lakes (Fig. 1). Data consisted of a random sample, including 177 lakes, and 30 additional lakes with the highest total phosphorus content from the Finnish Lake Survey database (see Mannio et al., 2000; Rantakari and Kortelainen, 2005 and Kortelainen et al., 2006 for details). The 30 lakes were included in order to balance the distribution of oligotrophic and eutrophic lakes in our $\mathrm{CH}_{4}$ study. In all, the Finnish Lake Survey database contains 874 lakes larger than 
Table 1. Lake type definitions.

\begin{tabular}{|c|c|c|c|}
\hline Lake Type & Abreviation & Definition & \\
\hline Nutrient rich and calcareous & NRC & Alkalinity $>0.4$ & Winter turbidity $>5$ FTU \\
\hline Clear, large & $\mathrm{CL}$ & Color $<30 \mathrm{Pt} \mathrm{mg} \mathrm{L}^{-1}$ & Area $\geq 40 \mathrm{~km}^{2}$ \\
\hline Clear, small and middle size & CSm\&M & Color $<30 \mathrm{Pt} \mathrm{mg} \mathrm{L}^{-1}$ & Area $<40 \mathrm{~km}^{2}$ \\
\hline Clear, shallow & $\mathrm{SSh}$ & Color $<30 \mathrm{Pt} \mathrm{mg} \mathrm{L}^{-1}$ & Mean depth $<3 \mathrm{~m}$ \\
\hline Humic, large & HL & Color $30-90 \mathrm{Pt} \mathrm{mg} \mathrm{L}^{-1}$ & Area $\geq 40 \mathrm{~km}^{2}$ \\
\hline Humic, middle size & $\mathrm{HM}$ & Color 30-90 Pt mg L ${ }^{-1}$ & Area $5-40 \mathrm{~km}^{2}$ \\
\hline Humic, small & $\mathrm{HSm}$ & Color $30-90 \mathrm{Pt} \mathrm{mg} \mathrm{L}^{-1}$ & Area $\leq 5 \mathrm{~km}^{2}$ \\
\hline Humic, shallow & $\mathrm{HSh}$ & Color $30-90 \mathrm{Pt}_{\mathrm{mg} \mathrm{L}}^{-1}$ & Mean depth $<3 \mathrm{~m}$ \\
\hline Very humic & VH & Color $>90 \mathrm{Pt} \mathrm{mg} \mathrm{L}^{-1}$ & Mean depth $\geq 3 \mathrm{~m}$ \\
\hline Very humic, shallow & VHSh & Color $>90 \mathrm{Pt} \mathrm{mg} \mathrm{L}^{-1}$ & Mean depth $<3 \mathrm{~m}$ \\
\hline
\end{tabular}

four hectares $\left(0.04 \mathrm{~km}^{2}\right)$, but our sample was restricted to lakes smaller than $100 \mathrm{~km}^{2}$. The data includes one eutrophic lake having a larger area.

The study lakes were situated in an area reaching from the margin of hemi/south boreal zone over the north boreal vegetation zone in Finland. Within this region the annual mean temperature ranges from -2.8 to $5.9^{\circ} \mathrm{C}$, annual precipitation varies from 449 to $879 \mathrm{~mm}$ (Finnish Meteorological Institute, 1999 and 2000), and the ice-covered period lasts about 5 months in the South and about 7 months in the North (Hyvärinen and Korhonen, 2003). Lakes in Finland are mostly of glacial origin, and set in non-calcareous granite bedrock or till. Shallow and small humic lakes are the most numerous. The catchments are largely forested, and peatlands are common. Generally, nitrogen and phosphorus concentrations are greatest in southern and western Finland and lowest in northern Finland (Mannio et al., 2000; Rantakari et al., 2004).

Lakes were typified according to the Finnish lake typology required for the ecological lake status classification governed by the EU water framework directive (Directive 2000/60/EC; Vuori et al., 2006). At first, the naturally nutrient rich and/or calcareous lakes were distinguished on the basis of alkalinity and winter turbidity (Table 1). The rest of the lakes were first divided into three groups according to their humic content using water color as a criterion, and then grouped according to the surface area and mean depth. The lake sample did not include any lakes above the northern tree line. Furthermore, the lakes with very short residence times were not identified. Some lakes were already typified by Finnish Regional Environmental Centres on the basis of long term observations (HERTTA register). For those lakes that had no pre-registered type, the type was derived on the basis of morphological and chemical data from our study. The surface water chemistry in autumn was used in typification. Winter turbidity was needed to determine the nutrient rich and calcareous type.

\subsection{Sampling and gas and water chemistry analyzes}

Each lake was sampled four times during either the year 1998 or the year 1999 in order to capture $\mathrm{CH}_{4}$ concentrations during potential winter and summer stratification and after spring and autumn overturn periods. Timing of sampling was thus as follows: 1) before thaw in March-April, 2) after thaw in May-June, 3) during late summer in the end of August-early September, and 4) in October. Water samples were drawn from 1) 1 meter below the surface, 2) in the middle of the water column, 3) 1 meter above the sediment surface, and 4) $0.2 \mathrm{~m}$ above the sediment surface - all at the deepest point of each lake. In very shallow lakes the amount of samples was smaller. Water samples of $30 \mathrm{ml}$ for $\mathrm{CH}_{4}$ concentration determination were drawn from the silicone tube of the Ruttner water sampler using a hypodermic needle and $60 \mathrm{ml}$ polypropylene syringes equipped with three-way stopcocks. In addition, water temperature was recorded and water samples for chemical analyses were collected.

Water samples were transported in coolers to the laboratories of the universities of Kuopio and Joensuu, where analyses of dissolved $\mathrm{CH}_{4}$ concentrations were conducted the day after sampling. According to the headspace equilibration technique (McAuliffe, 1971), $30 \mathrm{ml}$ ultra pure $\mathrm{N}_{2}$ gas was added to each syringe and shook vigorously for 3 minutes. The headspace gas $\mathrm{CH}_{4}$ concentration was quantified with a gas chromatograph (Hewlett Packard Series II and Shimadzu GC-14-A) equipped with an FI-detector. The $\mathrm{CH}_{4}$ concentration dissolved in water was calculated from the headspace gas concentration according to Henry's law using the values after Lide and Fredrikse (1995).

Oxygen, alkalinity, turbidity, $\mathrm{pH}$, water color, total nitrogen (Ntot), total phosphorus (Ptot), and total organic carbon (TOC) were analysed from unfiltered samples in the laboratories of the Regional Environment Centres (National Board of Waters, 1981). Oxygen was determined by adding $\mathrm{H}_{3} \mathrm{PO}_{4}$ to the sample in the field and titration of the acidified sample in the laboratory with the Winkler method. Alkalinity 
was measured by Gran titration. Conductivity was measured conductometrically with temperature compensating cell. The values of $\mathrm{pH}$ were obtained electrometrically at $25^{\circ} \mathrm{C}$ with a $\mathrm{pH}$ meter. Water color (milligrams platinium per liter) was measured by optical comparison with standard platinum cobalt chloride disks. Total nitrogen was determined by oxidation with $\mathrm{K}_{2} \mathrm{~S}_{2} \mathrm{O}_{8}$. Total phosphorus was measured with spectrophotometer. Total organic carbon was determined by oxidizing the sample by combustion and measuring $\mathrm{C}$ using IR-spectrophotometry.

\subsection{Morphometric and catchment characteristics}

Data on area, mean depth, total volume and volume of water layers for the lakes in the sample were either derived from the register or measured directly in this study. If lake basin volume was not available in the register, it was estimated using regressions based on representative lake data $(n=1831)$ available in the Finnish Environment Institute. The catchment boundaries were interpreted using topographic maps, and were digitized. We used a Landsat TM grid and digital elevation model with ArcView geo-referencing software to obtain catchment and lake areas, catchment to lake ratios, and proportions of agricultural land, peatlands, and forests on upland soil, and areas of water and human settlements. The peatland category included both pristine and forestry drained areas.

\subsection{Calculation of $\mathrm{CH}_{4}$ fluxes and $\mathrm{CH}_{4}$ storage in water}

Annual flux estimate is the sum of the spring and fall storage change fluxes and the diffusive efflux over the open water period. Ebullition was not measured and it is not part of the estimate. Fluxes were calculated for the whole lake and then divided by the lake area to get estimate per unit area. The diffusion rate between the water and the atmosphere was estimated on the basis of surface water $\mathrm{CH}_{4}$ concentration.

The diffusive flux $F\left(\mathrm{~mol} \mathrm{~m}^{-2} \mathrm{~d}^{-1}\right)$ between the water surface and the atmosphere was calculated as:

$$
F=k \times(C w-C e q)
$$

where $k$ is the gas transfer coefficient $\left(\mathrm{md}^{-1}\right)$ and $\mathrm{C}_{w}$ the measured $\mathrm{CH}_{4}$ concentration $\left(\mathrm{mol} \mathrm{m}^{-3}\right)$ in the surface water (at the depth of $1 \mathrm{~m}$ ) and $C_{e q}$ the methane concentration in water that is in equilibrium with the atmosphere at in situ temperature. The $\mathrm{CH}_{4}$ concentration in the lake water in equilibrium with the atmosphere was calculated assuming the atmospheric $\mathrm{CH}_{4}$ concentration of $1.72 \mu \mathrm{LL}^{-1}$ for the year 1994 and taking into account the annual increase of $0.01 \%$ (Houghton et al., 1996). Gas transfer coefficient $k$ was estimated according to Cole and Caraco (1998). They determined experimentally $k$ for tracer gas SF6 in small sheltered lake and normalized it to Schmidt number $600\left(\mathrm{CO}_{2}\right.$ at temperature of $20^{\circ} \mathrm{C}$ ). An empirical relationship between wind speed and $k_{600}$ value based on several tracer studies (Cole and Caraco, 1998), was used to determine $k_{600}\left(\mathrm{~cm} \mathrm{~h}^{-1}\right)$ :

$k_{600}=2.07+0.215 \times U_{10}^{1.7}$

where $U_{10}$ denotes the wind speed at $10 \mathrm{~m}$ height. We applied a value of $3 \mathrm{~m} \mathrm{~s}^{-1}$, which is the average wind speed at $10 \mathrm{~m}$ height in the inland stations of Finnish Meteorological Institute during the open water period.

When piston velocity is known for one gas and temperature, it can be applied to another gas and temperature by the ratio of the Schmidt numbers. To calculate $k$ for $\mathrm{CH}_{4}$ we used

$k \mathrm{CH}_{4}=k_{600} \times\left(S c_{\mathrm{CH}_{4}} / 600\right)^{-0.5}$,

where Schmidt numbers for $\mathrm{CH}_{4}\left(\mathrm{Sc}_{\mathrm{CH}_{4}}\right)$ evaluated for particular temperature and water density were calculated from empirical third-order polynomial fit with water temperature as an independent variable (Jähne et al., 1987). For the exponent we used value -0.5 according to Hamilton et al. (1994) and MacIntyre et al. (1995).

To calculate the diffusive flux over the whole ice-free period, the before ice-out concentration was extrapolated over 0.5 months after the ice-out. Similarly, the after ice-out concentration was assumed to last for 1.5 months, the summer time concentration for 3 months, and the autumn concentration over 2 months of the ice-free period of 7 months. These same periods were used when estimating the $\mathrm{CO}_{2}$ emissions from our lakes (Kortelainen et al., 2006). In the current study, time spans were proportionally the same for lakes having shorter ice-free period.

The $\mathrm{CH}_{4}$ storage was calculated for the water column $\left(\mathrm{m}^{2}\right)$ at sampling points and for whole lakes by multiplying concentration values by the volume of each layer assuming horizontal mixing of $\mathrm{CH}_{4}$. Storage change fluxes were calculated from the differences in $\mathrm{CH}_{4}$ storage between winter and spring, and between late summer and autumn. This flux compared with the estimate of potential flux. Potential flux is the $\mathrm{CH}_{4}$ storage exceeding the equilibrium concentration in the water column during late winter and late summer, which is is assumed to be released to the atmosphere during circulation (Michmerhuizen et al., 1996). If storage was larger during spring and autumn than during late winter and late summer, the larger storage was used to calculate storage flux, since the timing of the sampling might have been too early. Methane storage in the water column at sampling point $\left(\mathrm{m}^{2}\right)$ was calculated by extrapolating the measured dissolved $\mathrm{CH}_{4}$ concentration over depth ranges $0-0.5 \mathrm{~m}$ above the sediment, 0.5-2 $\mathrm{m}$ above sediment, $2 \mathrm{~m}$ above sediment to $2 \mathrm{~m}$ below the lake surface, and $2-0 \mathrm{~m}$ below the lake surface. The weighted estimate was produced by calculating storage in the whole volume of lake, integrating storage in the above depth ranges and dividing it by lake area. 


\subsection{Data analyses}

Statistical distributions of $\mathrm{CH}_{4}$ concentrations and fluxes are presented for the different lake types. We used multiple linear regression analysis (SPSS 15.0 for Windows) to quantify relationships between environmental variables and $\mathrm{CH}_{4}$ concentration during different phases of the annual lake cycle. Correlations among methane, climatic, chemical and morphological variables were inspected using regression and principal component analyses. Those showed that many of the chemical variables determined for the water samples typically correlate strongly with each other. A limited set of variables were kept in further analyses. Effect of area, maximum depth, mean depth, area:maximum depth, area:mean depth, oxygen saturation, Ptot, Ntot, TOC, Ptot:TOC, mean annual temperature, and water temperature on the $\mathrm{CH}_{4}$ concentrations was examined. Each variable was used as an independent variable alone. Thirdly, selected variable combinations were used to build regression models. Patterns within humic categories were examined, and lake types of different size categories but with same humic content (Table 1) were pooled into one group in order to increase the number of observations in the group and to facilitate the statistical analyses. In the tables we give results only for the whole data. Relationships between central values of some environmental variables and $\mathrm{CH}_{4}$ flux components for the lake types were explored visually (Fig. 6) and by regression analysis. For the concentrations, near-bottom and surface water samples were analysed independently during both the late summer (summer stratification) and the late winter (winter stratification). $\log _{e}$ and $\operatorname{arc} \sin \sqrt{ } x$ were used for unevenly distributed data.

We also examined the relationship between the $\mathrm{CH}_{4}$ concentration in near-bottom water in winter or summer and the lake status in terms of phosphorus and oxygen. For this purpose the lakes were divided in groups according to their total phosphorus concentration and occurrence of anoxia in the near-bottom water. Three groups were identified according to total phosphorus: Ptot $<30 \mu \mathrm{g} \mathrm{L}^{-1}, 30 \leq$ Ptot $\leq 50 \mu \mathrm{g} \mathrm{L}^{-1}$, Ptot $>50 \mu \mathrm{g} \mathrm{L}^{-1}$. Four groups were identified according to anoxia: Lakes never facing anoxia, and the lakes in which the near bottom water was anoxic either in winter or summer, or more often. The water was considered anoxic if $\mathrm{O}_{2}$ saturation was below 5\%. Differences in mean $\mathrm{CH}_{4}$ concentrations between the categories were tested using the MannWhitney U-test. Differences in catchment land cover between these groups were similarly tested. We also show central $\mathrm{CH}_{4}$ emissions estimates for the lakes of statistic sample (177 lakes) in size classes $0.04-<0.1,0.1-<0.5,0.5-<1,1-$ $<10,>10 \mathrm{~km}^{2}$.

\section{Results}

\subsection{Distribution of lake types}

The most numerous lake types were very humic shallow (VHSh), humic shallow (HSh) and nutrient rich and calcareous (NRC) (Table 2). The surface area of lakes ranged from 0.04 to $119.8 \mathrm{~km}^{2}$. The median lake area was $0.28 \mathrm{~km}^{2}$ and only $25 \%$ of the lakes had an area over $1.6 \mathrm{~km}^{2}$. Most of those small lakes were typified into the three shallow types (Table 2). Most NRC lakes were also shallow and had a small area. Defined by color $\left(\mathrm{Pt} \mathrm{mg} \mathrm{L}^{-1}\right)$, proportions of lakes with clear, humic or very humic water were $22 \%, 40 \%$, or $38 \%$, respectively. The lakes in type NRC included many highly humic lakes. Nutrient-rich and calcareous lakes, and very humic lakes were more common in the southern part of the study region, while the distributions of humic large, clear shallow, and humic small lakes were more northern. Catchments of NRC lakes had the greatest proportional cover of agricultural land, while proportional peatland cover was largest in the catchments of larger humic lakes and very humic lakes. Very humic lakes and NRC lakes had small water area in catchments and large catchments relative to the lake size. Those lake types had the greatest total nutrient concentrations; in humic lakes the nutrients are largely bound in organic matter (Table 2).

\subsection{Methane concentrations}

Average surface water $\mathrm{CH}_{4}$ concentration was $1.0 \mu \mathrm{mol} \mathrm{L}^{-1}$, and the bottom water concentration averaged $20.6 \mu \mathrm{mol} \mathrm{L}^{-1}$, yet it was less than $2.3 \mu \mathrm{mol} \mathrm{L}^{-1}$ in $75 \%$ of the lakes. Very high $\mathrm{CH}_{4}$ concentrations were rare (three samples had concentration over $1000 \mu \mathrm{mol} \mathrm{L}^{-1}$ ) (Table 3). Methane concentrations were generally greatest in the water layer closest to the sediment during late winter ( $\mathrm{md} 7.9 \mu \mathrm{mol} \mathrm{L}^{-1}$ ), and during late summer (md $0.3 \mu \mathrm{mol} \mathrm{L}^{-1}$ ). The surface water concentrations were most often the largest during the late summer, the median value being $0.2 \mu \mathrm{mol} \mathrm{L}^{-1}$. The vertical concentration gradient was the largest during the late winter (Table 3, Fig. 2). Median concentration in the bottom was 113 times and 1.6 times the surface concentration under the ice cover and during the late summer, respectively. The relationship between bottom and surface water $\mathrm{CH}_{4}$ concentrations was weak. It was significant among all the lakes $\left(r^{2}=0.14\right)$, and among the clear small and middle size and shallow lakes, humic shallow and very humic lakes during the stratification periods.

Lake type characteristics were reflected in $\mathrm{CH}_{4}$ concentrations, but within each lake type the variation in $\mathrm{CH}_{4}$ concentrations was considerable. Statistical relationships between $\mathrm{CH}_{4}$ concentrations and environmental variables were weak though significant in the large data (Table 4). General pattern was that surface water $\mathrm{CH}_{4}$ concentration was more related to the morphological variables while the bottom water $\mathrm{CH}_{4}$ 


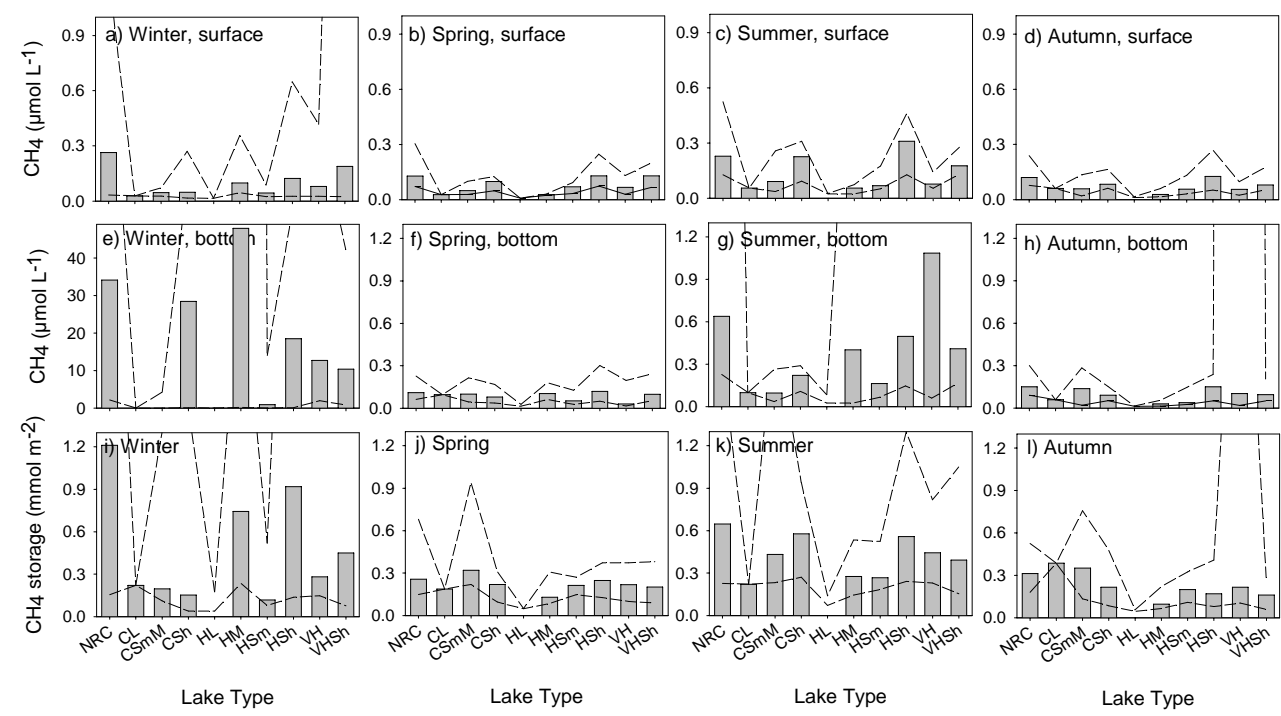

Fig. 2. $\mathrm{CH}_{4}$ concentrations and $\mathrm{CH}_{4}$ storages (whole lake integrated, mmol m${ }^{-2}$ ) in the different lake types (see Table 1). Bars show medians of surface (a-d) and bottom water $\mathrm{CH}_{4}$ concentrations (e-h), and the $\mathrm{CH}_{4}$ storages (i-l). Upper and lower quartiles are marked with dashed lines (these mark the two lakes in the type HL). Note the different scales and that some upper quartiles are outside of the scale.

Table 2. Medians for alkalinity, turbidity, Ptot, Ntot, color and TOC of the surface water at fall, lake area (A), maximum depth (D) and proportional cover of agricultural land (Agr.), forests (For.), peat and water (Wat) in the catchments in the whole data and the different lake types. Mean annual temperature (T) was measured in the nearest weather stations (Finnish Meteorological Institute 1999 and 2000). Three lakes could not be typified due to missing water chemistry data, and land cover distribution was analyzed only for 187 lakes. Type definitions from the Table 1.

\begin{tabular}{lccccccccccccccc}
\hline Lakes & $\mathrm{N}$ & Alk. & Turb. & Ptot & Ntot & Color & TOC & A & D & T & pH & Agr. & For. & Peat & Wat. \\
\hline & & $\left(\mathrm{mmol}^{-}\right)$ & $(\mathrm{FTU})$ & $\left(\mu \mathrm{g} \mathrm{l}^{-1}\right)$ & $\left(\mu \mathrm{g} \mathrm{l}^{-1}\right)$ & $\left(\mathrm{Pt} \mathrm{mg} \mathrm{l}^{-1}\right)$ & $\left(\mathrm{mg} \mathrm{l}^{-1}\right)$ & $\left(\mathrm{km}^{2}\right)$ & $(\mathrm{m})$ & $\left({ }^{\circ} \mathrm{C}\right)$ & & $(\%)$ & $(\%)$ & $(\%)$ & $(\%)$ \\
\hline Stat. & 177 & 0.1 & 1.3 & 14 & 460 & 70 & 9 & 0.24 & 6.2 & 3.2 & 6.5 & 2.6 & 67 & 12 & 9 \\
Eutr. & 30 & 0.2 & 6.5 & 60 & 970 & 140 & 11 & 0.94 & 4.0 & 3.6 & 6.6 & 11.6 & 61 & 17 & 5 \\
All & 207 & 0.1 & 1.5 & 16 & 505 & 80 & 9 & 0.28 & 6.0 & 3.3 & 6.6 & 3.6 & 67 & 12 & 8 \\
Types & & & & & & & & & & & & & & & \\
NRC & 27 & 0.4 & 5.3 & 57 & 840 & 75 & 9 & 0.52 & 5.1 & 4.1 & 6.8 & 20.4 & 60 & 2 & 7 \\
CL & 1 & 0.2 & 1.1 & 15 & 280 & 15 & 5 & 44.26 & 26.5 & 3.1 & 7.2 & 4.2 & 72 & 6 & 17 \\
CSm\&M & 17 & 0.1 & 0.6 & 6 & 270 & 15 & 4 & 1.35 & 13.4 & 3.2 & 6.7 & 2.3 & 68 & 6 & 19 \\
CSh & 21 & 0.1 & 0.7 & 6 & 300 & 20 & 5 & 0.14 & 6.2 & 1.5 & 6.8 & 0.0 & 69 & 5 & 13 \\
HL & 2 & 0.2 & 1.3 & 16 & 300 & 60 & 9 & 52.75 & 17.8 & 0.1 & 7.1 & 0.9 & 60 & 29 & 10 \\
HM & 4 & 0.2 & 0.9 & 11 & 510 & 35 & 8 & 20.17 & 15.6 & 3.6 & 7.0 & 3.8 & 58 & 18 & 17 \\
HSm & 19 & 0.1 & 1.0 & 11 & 360 & 50 & 8 & 1.03 & 14.0 & 2.2 & 6.5 & 3.0 & 71 & 9 & 11 \\
HSh & 45 & 0.1 & 1.3 & 14 & 485 & 65 & 9 & 0.19 & 4.0 & 2.8 & 6.5 & 4.2 & 70 & 11 & 10 \\
VH & 11 & 0.1 & 1.6 & 31 & 635 & 170 & 16 & 1.40 & 12.5 & 3.3 & 6.3 & 10.0 & 64 & 19 & 5 \\
VHSh & 57 & 0.1 & 2.0 & 24 & 635 & 160 & 17 & 0.10 & 3.8 & 3.4 & 6.3 & 1.5 & 63 & 22 & 5 \\
\hline
\end{tabular}

concentration was related to oxygen and nutrient concentrations (Table 4, Fig. 3). Methane concentration in bottom water correlated with morphology only during summer, but not under the ice over.

Surface water $\mathrm{CH}_{4}$ concentration was primarily related to lake depth. Both in winter and summer medians of $\mathrm{CH}_{4}$ concentration were greatest in the shallow lake types. The medians varied from 0.12 in HSh to $0.26 \mu \mathrm{mol} \mathrm{L}^{-1}$ in NRC during winter and from 0.18 for VHSh to $0.31 \mu \mathrm{mol} \mathrm{L}^{-1}$ for
HSh during summer (Fig. 2a-d). Surface water $\mathrm{CH}_{4}$ concentration correlated negatively with the lake depth, oxygen saturation, and positively with concentrations of Ptot and TOC during winter (Table 4). There was a weak positive correlation with mean annual temperature. During summer, surface water $\mathrm{CH}_{4}$ concentration had negative correlation with lake area, depth, and area to depth ratio, and weakly negative correlation with oxygen saturation. 
Table 3. Statistical distributions of $\mathrm{CH}_{4}$ concentrations $\left(\mu \mathrm{mol} \mathrm{L}{ }^{-1}\right)$ in $1 \mathrm{~m}$ below surface (surface) and $0.2 \mathrm{~m}$ above the sediment (bottom).

\begin{tabular}{llllllll}
\hline Depth & Sampling & Mean & Lower & Median & Upper & Max & $\mathrm{N}$ \\
\hline \multicolumn{7}{c}{ quartile } & \multicolumn{5}{c}{ quartile } \\
\hline Bottom & Winter & 53.62 & 0.13 & 7.94 & 47.31 & 3013.76 & 192 \\
Bottom & Spring & 3.23 & 0.05 & 0.10 & 0.20 & 227.39 & 196 \\
Bottom & Summer & 21.49 & 0.12 & 0.27 & 3.18 & 1331.15 & 183 \\
Bottom & Autumn & 4.25 & 0.05 & 0.10 & 0.23 & 393.33 & 190 \\
Surface & Winter & 3.39 & 0.03 & 0.07 & 0.55 & 60.19 & 201 \\
Surface & Spring & 0.16 & 0.05 & 0.10 & 0.19 & 2.50 & 203 \\
Surface & Summer & 0.25 & 0.08 & 0.17 & 0.31 & 1.69 & 200 \\
Surface & Autumn & 0.24 & 0.04 & 0.08 & 0.18 & 5.12 & 201 \\
\hline
\end{tabular}

Table 4. Relationships between $\mathrm{CH}_{4}$ concentrations and environmental variables that correlated significantly with $\mathrm{CH}_{4}$ at $p$ level $<0.05$. Sign indicating positive or negative correlations and the regression coefficient are given before and after the variable, respectively. Effect of area, maximum depth, mean depth, area:maximum depth, area:mean depth, oxygen saturation, Ptot, Ntot, TOC, Ptot:TOC, mean annual temperature, and water temperature on the $\mathrm{CH}_{4}$ concentrations was examined. Effect of each factor was tested independently in regression analysis.

\begin{tabular}{|c|c|c|c|}
\hline Winter, Surface & Summer, surface & Winter, bottom & Summer, bottom \\
\hline $\begin{array}{l}\text {-Max depth, } 0.24 \\
\text {-Mean depth, } 0.23 \\
-\mathrm{O}_{2} \%, 0.22 \\
\text { +Ptot, } 0.17 \\
\text { +TOC, } 0.09 \\
\text { +Ptot:TOC, } 0.07 \\
\text { +Mean T, } 0.02\end{array}$ & $\begin{array}{l}\text { - Area, } 0.11 \\
\text { - Max depth, } 0.10 \\
\text { - Mean depth, } 0.08 \\
\text { - Area:mean depth, } 0.06 \\
\text { - Area:max depth, } 0.06 \\
\text { - } \mathrm{O}_{2} \%, 0.02\end{array}$ & $\begin{array}{l}-\mathrm{O}_{2} \%, 0.51 \\
\text { +Ptot, } 0.29 \\
\text { +Ptot:TOC, } 0.17 \\
\text { +TOC, } 0.05 \\
\text { +Water T, } 0.02\end{array}$ & $\begin{array}{l}-\mathrm{O}_{2} \%, 0.38 \\
+ \text { Ptot, } 0.16 \\
\text { +Ptot:TOC, } 0.07 \\
\text { - Area, } 0.06 \\
\text { - Area:mean depth, } 0.06 \\
\text { - Area:max depth, } 0.06 \\
\text { +TOC, } 0.05 \\
\text { +Water T, } 0.03\end{array}$ \\
\hline
\end{tabular}

Bottom water $\mathrm{CH}_{4}$ concentration was the highest in winter in the large humic lakes (HL, HM), CSh and NRC lakes, for those the medians were from 28.43 to $81.12 \mu \mathrm{mol} \mathrm{L}^{-1}$ (Fig. 2e-h). These were followed by the smaller humic and very humic lakes, and the types $\mathrm{HSh}>\mathrm{VH}>\mathrm{VHSh}$ had medians from 10.38 to $18.5 \mu \mathrm{mol} \mathrm{L}^{-1}$. During summer the deeper very humic $(\mathrm{VH})$ lakes had the greatest bottom concentrations (md $1.08 \mu \mathrm{mol} \mathrm{L}^{-1}$ ). Large $\mathrm{CH}_{4}$ concentrations were common also in NRC lakes and in the other humic lakes (HSh $>\mathrm{HM}>\mathrm{VHSh}$ ). Bottom water $\mathrm{CH}_{4}$ concentration in winter and summer alike correlated negatively with oxygen saturation and positively with Ptot concentration and Ptot:TOC ratio (Table 4). It correlated weakly with TOC concentration and water temperature. During summer, $\mathrm{CH}_{4}$ concentration had also negative correlation with lake area and area-to-depth ratio. The most extreme cases $\left(\mathrm{CH}_{4}\right.$ $>1000 \mu \mathrm{mol} \mathrm{L}^{-1}$ ) were not associated with anoxic water, and possibly sediment interstitial water was mixed with the lower water layers during sampling in those cases.

Stepwise regression models with $\mathrm{O}_{2}$ saturation, Ptot, mean depth and area as independent variables explained up to $34 \%$ of variation in surface water $\mathrm{CH}_{4}$ concentration and up to $59 \%$ of variation in bottom water $\mathrm{CH}_{4}$ concentration when all lakes were included (Table 5). All of these parameters did not get significant parameter values in the humic class specific models, which likely indicate shorter environmental gradients within a humic class than in the complete data set. For example, oxygen saturation seemed to be insignificant factor in NRC lakes, because the majority of those lakes suffered oxygen deficiency during the late winter.

\subsection{Dissolved $\mathrm{CH}_{4}$ and lake status}

Methane concentration of bottom close water could be viewed as an indicator of lake status in terms of oxygen and nutrients. In the late winter, the $\mathrm{CH}_{4}$ concentrations were significantly greater in the lakes suffering anoxia and having the highest Ptot levels (Md 151.1 $\mu \mathrm{mol} \mathrm{L}^{-1}$ ) than in the lakes in which bottom water stayed oxic and Ptot levels were low (Md $0.1 \mu \mathrm{mol} \mathrm{L}^{-1}$ ) (Fig. 4a, Table 6). The difference in $\mathrm{CH}_{4}$ concentrations between these two categories was smaller although statistically significant also during the late summer (Fig. 4b). Within any category of anoxia, 
Table 5. Linear regression models for the $\mathrm{CH}_{4}$ concentrations. The predicting variables were entered to the stepwise analysis in the order $\mathrm{O}_{2}$ saturation, Ptot, maximum depth and area. All models are significant at level $p>0.01$, and all parameter values are significant at level $p>0.05$ (ns=non significant).

\begin{tabular}{lccccccc}
\hline \multicolumn{7}{c}{ Parameters } \\
\hline Set & $r_{\text {adj. }}^{2}$ & $D f_{\text {res }}$ & Constant & $\mathrm{O}_{2}$ sat. & Ptot & Max Depth & Area \\
\hline Winter, surface & 0.34 & 191 & 1.431 & -0.882 & 0.178 & -0.426 & 0.168 \\
Winter, bottom & 0.59 & 186 & 2.048 & -0.872 & 0.490 & ns. & -0.308 \\
Summer, surface & 0.16 & 188 & 0.322 & ns. & ns. & -0.050 & -0.043 \\
Summer, bottom & 0.46 & 176 & 2.702 & -2.138 & 0.230 & -0.465 & ns. \\
\hline
\end{tabular}

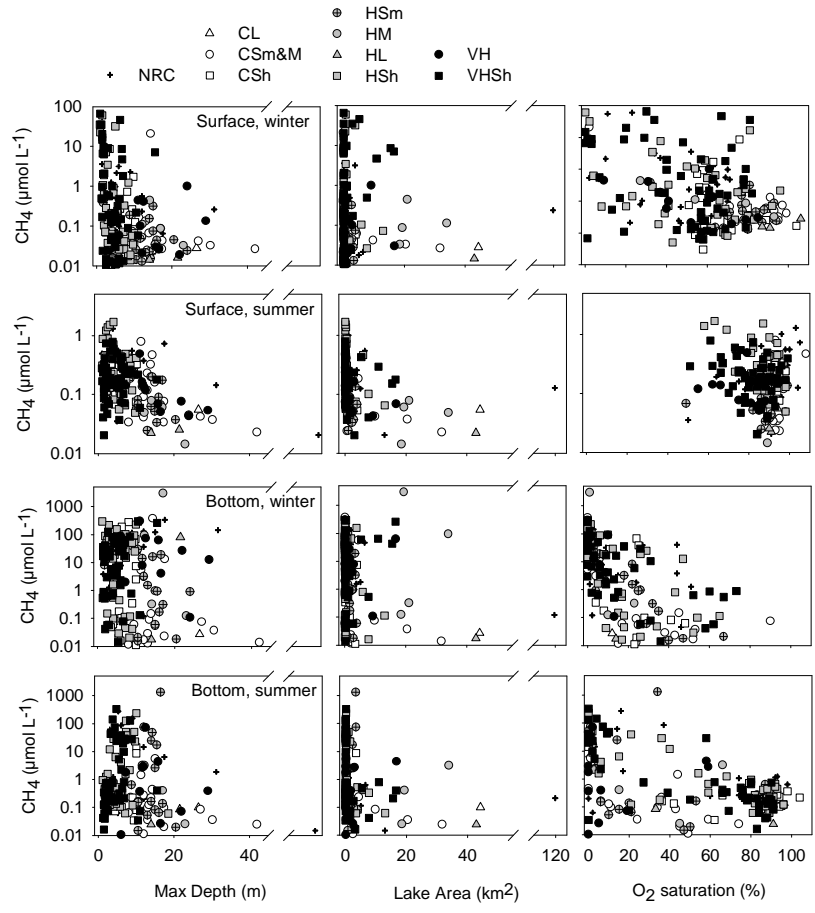

Fig. 3. Surface and bottom water $\mathrm{CH}_{4}$ concentrations before the potential over-turn periods during late winter and late summer in relation to maximum depth (left), lake area (middle), and oxygen saturation (right).

the $\mathrm{CH}_{4}$ concentrations increased with increasing Ptot level. The lakes where the near-bottom water stayed oxic over the whole annual cycle had significantly smaller $\mathrm{CH}_{4}$ concentrations than the lakes where near-bottom water turned anoxic at least once during the annual cycle (Table 6). Among the lakes where near-bottom water was anoxic at least once or more during a year, the lakes having the lowest Ptot level had also significantly smaller $\mathrm{CH}_{4}$ concentrations than the lakes with higher Ptot levels $(p<0.01)$ during winter. The difference between these lake categories was not significant during the summer $(p=0.985)$.
Table 6. Bottom water $\mathrm{CH}_{4}$ concentrations in the lakes classified according to mean total phosphorus concentration and occurrence of anoxia over a year in bottom water. Results of different comparisons among anoxia and Ptot categories in winter and summer, are separated by a row. The categories with no letter common are significantly different.

\begin{tabular}{llllll}
\hline \multicolumn{5}{c}{$\mathrm{CH}_{4}\left(\mu \mathrm{mol} \mathrm{L}^{-1}\right)$} \\
\hline & Category & Mean & Md & SD & N \\
\hline Winter & No anoxia, low P & $6.263^{\mathrm{a}}$ & 0.101 & 15.483 & 67 \\
Winter & Anoxia, high P & $185.045^{\mathrm{b}}$ & 151.106 & 117.62 & 14 \\
Winter & No anoxia & $8.828^{\mathrm{a}}$ & 0.325 & 17.703 & 95 \\
Winter & Anoxia, Ptot $<30$ & $43.203^{\mathrm{b}}$ & 29.079 & 56.621 & 57 \\
Winter & Anoxia, Ptot $>30$ & $89.242^{\mathrm{c}}$ & 57.05 & 100.249 & 47 \\
Summer & No anoxia, low P & $2.037^{\mathrm{a}}$ & 0.132 & 8.347 & 66 \\
Summer & Anoxia, high P & $58.558^{\mathrm{b}}$ & 6.36 & 80.369 & 11 \\
Summer & No anoxia & $3.428^{\mathrm{a}}$ & 0.159 & 13.009 & 93 \\
Summer & Anoxia, Ptot $<30$ & $17.649^{\mathrm{b}}$ & 1.25 & 42.409 & 55 \\
Summer & Anoxia, Ptot $>30$ & $31.283^{\mathrm{b}}$ & 0.779 & 69.6 & 42 \\
\hline
\end{tabular}

Water was considered anoxic when $\mathrm{O}_{2}$ saturation was below $5 \%$. No anoaxia, Low P: Ptot below $30 \mu \mathrm{g} \mathrm{L}^{-1}$, and bottom water never anoxic, Anoxia, high P: Ptot over $50 \mu \mathrm{g} \mathrm{L}^{-1}$, and bottom water was anoxic at two or more sampling times. Three cases with $\mathrm{CH}_{4}$ concentration over $1000 \mu \mathrm{g} \mathrm{L}^{-1}$ were not included in the analysis.

The catchments of lakes having prevailing anoxia and the highest Ptot levels had significantly larger proportions of settlement and agricultural land, and significantly smaller proportions of peatland and water than the catchments of the oxic and low Ptot lakes $(p<0.05)$. The large proportions of agricultural land and settlements in the catchments were particularly related to high Ptot levels.

\subsection{Methane storages}

Methane storage integrates the water volume and the concentration of $\mathrm{CH}_{4}$ in different water layers (Fig. 2i-1)., Methane storages were larger during the assumed stratification periods than during the following mixing or post mixing times, 


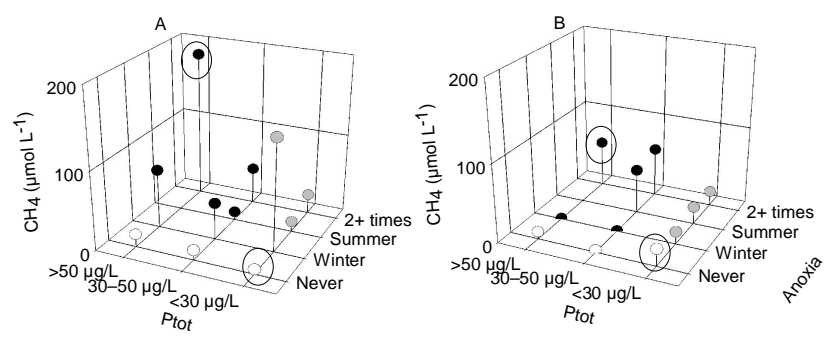

Fig. 4. Mean $\mathrm{CH}_{4}$ concentrations of the bottom close water in the winter (a) and the summer (b) in the lakes categorized by frequency of anoxia and total phosphorus (Ptot). The two extreme categories (circled) and the category groups never anoxic (open symbols), and at least sometimes anoxic low Ptot lakes (grey symbols), and at least sometimes anoxic high Ptot lakes (black symbols) were compared. For the comparisons see the Table 5.

spring and autumn, in $58 \%$ and $75 \%$ of the lakes, respectively. In those lakes median percentage of the storage that was lost during the assumed turn over was $88 \%$ in spring and $63 \%$ in autumn. The $\mathrm{CH}_{4}$ storage reached its seasonal maximum during late winter in $40 \%$ of the lakes, and during late summer in $36 \%$ of the lakes. In some lakes the storage peaked during spring $(11 \%)$ or in autumn $(13 \%)$. These might be lakes where the sampling possibly took place before the turn over.

Accumulation of substantial $\mathrm{CH}_{4}$ storage during summer was common among these lakes. Consequently, median of $\mathrm{CH}_{4}$ storage was larger during the late summer than during other times. Most lakes in the types CSh, VH, and HSh had summer-autumn maximum in their $\mathrm{CH}_{4}$ storage. Most lakes in the types HM, VHSh and NRC had peak storage during late winter-spring period. Overall, NRC lakes had larger $\mathrm{CH}_{4}$ storages than the other lake types both during winter and summer (Fig. 2i-l).

\subsection{Diffusive and storage fluxes to the atmosphere}

This flux estimate is the sum of the spring and fall storage change fluxes and the diffusive efflux over the open water period. Ebullition was not measured and it is not part of the estimate. Fluxes were calculated for the whole lake and then divided by the lake area to get estimates per unit area. The sum of $\mathrm{CH}_{4}$ fluxes (storage and diffusion) ranged from very low release of 2 to $1142 \mathrm{mmol} \mathrm{m}^{-2} \mathrm{a}^{-1}$. Median and mean $\mathrm{CH}_{4}$ fluxes for all of the lakes were 25 and $65 \mathrm{mmol} \mathrm{m}^{-2} \mathrm{a}^{-1}$, respectively (Fig. 5a), and for the 177 lakes in the statistic sample those were 21 and $49 \mathrm{mmol} \mathrm{m}^{-2} \mathrm{a}^{-1}$. Flux estimates for the sampling point only would be higher due to smaller proportion of surface water and larger proportion of storage flux, e.g. median for the set of 177 lakes was $45 \mathrm{mmol} \mathrm{m}^{-2} \mathrm{a}^{-1}$.

The sample of 30 eutrophic lakes had the highest median of $\mathrm{CH}_{4}$ emission (Fig. 5a). The emission was 3.5 times the median for the $\mathrm{CH}_{4}$ flux for the statistic lake sample.

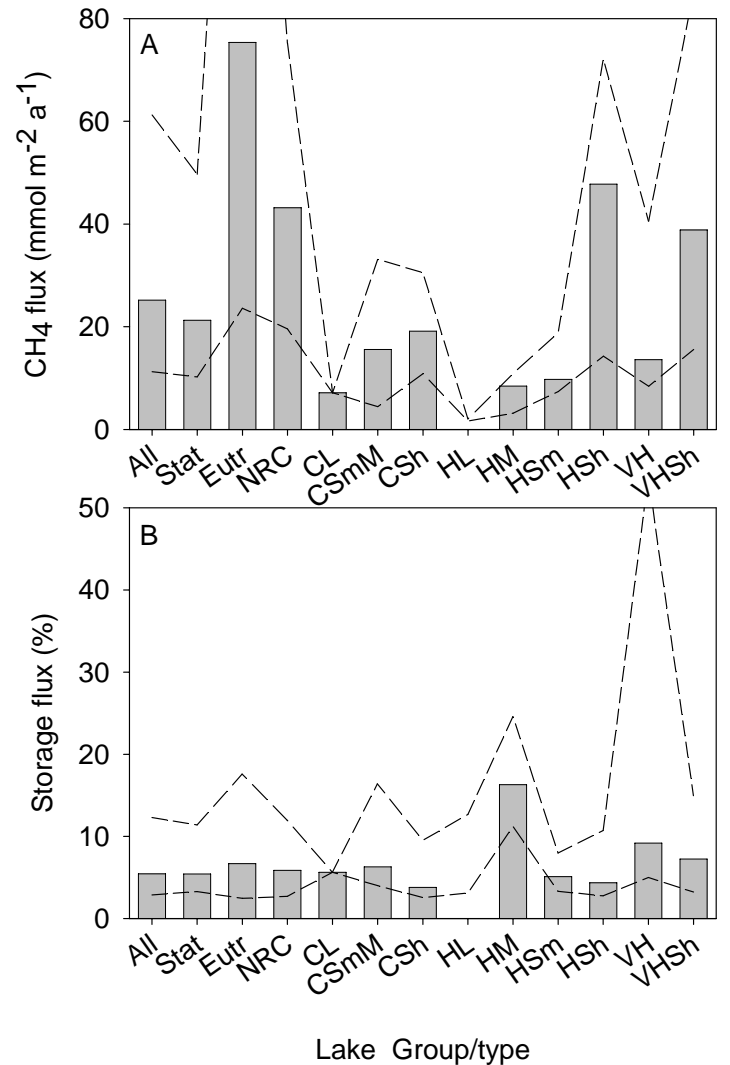

Fig. 5. Medians of $\mathrm{CH}_{4}$ flux estimates (sum of diffusive and storage fluxes, mmol m $\mathrm{m}^{-2} \mathrm{a}^{-1}$ ) (a) and the proportion of storage flux (b). Dashed lines indicate the upper and lower quartiles. Values are given for lake sets: All: 207 lakes, Stat: statistic lake sample $(n=177)$, Eutr: Eutrophic lakes $(n=30)$, NRC: nutrient rich and calcareous, CL: clear large, CSm\&M: clear small and middle size, CSh: clear shallow, LH: humic large $(n=2)$, HM: humic middle size, HSm: humic small, HSh: humic shallow, VH: very humic, and VHSh: very humic shallow.

The lakes in the shallow types had commonly higher $\mathrm{CH}_{4}$ fluxes (medians $19-48 \mathrm{mmol} \mathrm{m}^{-2} \mathrm{a}^{-1}$ ) than the larger lakes (2-8 $\left.\mathrm{mmol} \mathrm{m}^{-2} \mathrm{a}^{-1}\right)$. Lake types ordered according to median flux were $\mathrm{HSh}>\mathrm{NRC}>\mathrm{VHSh}>\mathrm{CSh}>\mathrm{CSm} \& \mathrm{M}>$ $\mathrm{VH}>\mathrm{HSm}>\mathrm{HM}>\mathrm{CL}>\mathrm{HL}$. The shallow types had high fluxes, because they had high surface water concentrations during summer leading to higher estimate of diffusive flux.

Diffusive flux dominated the $\mathrm{CH}_{4}$ release in most of the lakes, and the storage component was less than $5 \%$ of it in the half of the lakes (Fig. 5b). Storage fluxes could, however, make up to $91 \%$ of the sum, and the largest $\mathrm{CH}_{4}$ fluxes resulted from the large storage fluxes. Those occurred in large or deep lakes with substantial water volume. Storage fluxes of $\mathrm{CH}_{4}$ were usually larger in spring than in autumn. The lake types CSm\&M, VH, CSh, and VHSh had the greatest storage fluxes and proportionally it was largest in lake types HM and VH (Fig. 5b). 
Table 7. Regression models for the different flux components and their sum $\left(\mathrm{mmol} \mathrm{m}^{-2} \mathrm{a}^{-1}\right)$. Independent variables were given in the order of maximum depth $(\mathrm{m})$, lake area $\left(\mathrm{km}^{2}\right)$, and $\operatorname{Ntot}\left(\mu \mathrm{g} \mathrm{L}^{-1}\right)$ for the stepwise linear regression analysis. Ptot as an independent variable produced very similar result than Ntot.

\begin{tabular}{llcccc}
\hline Component & Model & $r^{2}$ & $D_{\text {res }}$ & $F$ & $p$ \\
\hline Sum & $\mathrm{y}=0.202-0.285 \times$ MaxD-0.206 $\times$ Area+0.548 $\times$ Ntot & 0.34 & 196 & 35.7 & $<0.001$ \\
Spring Storage & $\mathrm{y}=1.239-0.211 \times$ MaxDepth & 0.03 & 198 & 6.0 & 0.015 \\
Autumn Storage & $\mathrm{y}=-2.912-0.211 \times$ Area+0.383 $\times$ MaxDepth+0.426 $\times$ Ntot & 0.25 & 196 & 23.3 & $<0.001$ \\
Sum of Storages & $\mathrm{y}=-1.615-0.168 \times$ Area+0.432 $\times$ Ntot & 0.11 & 197 & 12.9 & 0.015 \\
Diffusion & $\mathrm{y}=0.558-0.360 \times$ MaxDepth $-0.179 \times$ Area+0.488 $\times$ Ntot & 0.37 & 196 & 40.6 & $<0.001$ \\
\hline
\end{tabular}
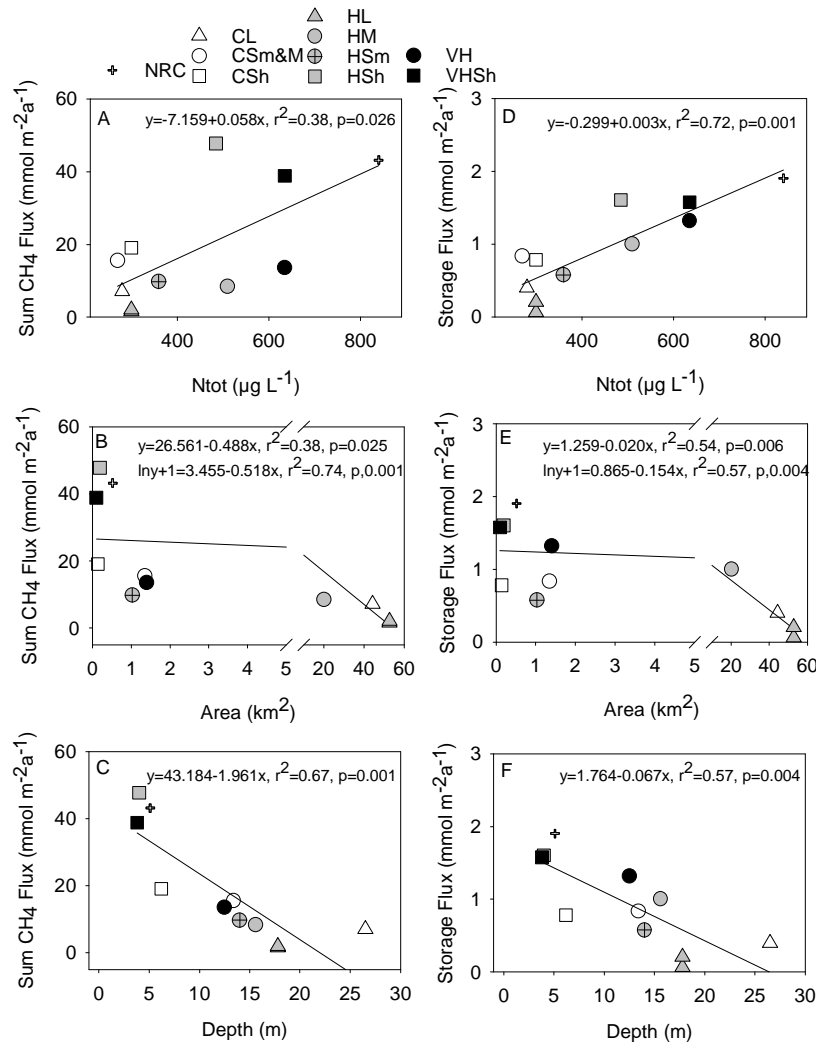

Fig. 6. Relationships between type specific central values of environmental variables and $\mathrm{CH}_{4}$ fluxes. Sum flux includes diffusive and storage fluxes and is dominated by the diffusion component (ac). Storage $\mathrm{CH}_{4}$ flux is sum of spring and autumn storages (d-f).

Regression models with maximum depth, lake area and Ntot (or Ptot) as independent variables explained 3-37\% of the variation in different flux components (Table 7). Diffusion components and sum of diffusion and storage fluxes were related to lake area and depth, and to nutrient status. Storage component showed variability that was harder to predict, and there may be size dependent differences in the relationships. Maximum depth received positive coefficient value for the autumn storage fluxes, while the coefficient was negative in the diffusion component model. Relationships between mean values of $\mathrm{CH}_{4}$ fluxes and environmental variables (see Table 2) for the lake types hide much of the details and the variation, but those illustrated the major factors associated with the variation in $\mathrm{CH}_{4}$ fluxes (Fig. 6). Large storage fluxes were related to eutrophic lake environments (Fig. 6d), high Ntot concentration and large agricultural land cover in the catchment, but also to small area. The sum of diffusive and storage fluxes was higher in the shallow and small lakes than in the large lakes. Among the small lakes, however, the more eutrophic and more humic lakes had higher fluxes than the clear ones (Fig. 6a-c).

\section{Discussion}

We present data on $\mathrm{CH}_{4}$ concentrations and storage change and diffusive fluxes derived from the concentrations. Our data are unique in the number of lakes examined, and statistic sample of the lakes and large geographical area provided some extensive environmental gradients. Lakes within this sample are typically small and humic. Globally, however, small lakes dominate: one third of the total world lake surface area consists of lakes that are smaller than $0.1 \mathrm{~km}^{2}$, and the estimated global average of lake size is $0.012 \mathrm{~km}^{2}$ (Downing et al., 2006). All of the lakes in our study were $0.04 \mathrm{~km}^{2}$ or larger, and consequently median lake area in the current study, $0.28 \mathrm{~km}^{2}$, is larger than the estimate of average global lake area.

The $\mathrm{CH}_{4}$ concentration in lake water is affected by many processes, and the large overall variability in $\mathrm{CH}_{4}$ concentrations in this study may result from the large data. These facts may contribute to the rather weak statistical relationships between $\mathrm{CH}_{4}$ and environmental variables in this study. We applied a regional lake typology to group lakes that have more similar physical and biological processes contributing to the $\mathrm{CH}_{4}$ within those groups. Results indicate that that the grouping factors, natural nutrient content, humic content, area and depth, are associated with the variation in $\mathrm{CH}_{4}$ concentration and with the flux estimates derived from the concentrations. 
The lake types are defined for assessing the ecological status of lakes in relation to each type's natural conditions (Directive 2000/60/EC; Vuori et al., 2006). At the time being we could not relate $\mathrm{CH}_{4}$ data with ecological status categories, because the work by the environmental authorities is still continuing. Status changes are indicated by changes e.g. in abundance and primary production of aquatic macrophyte or planktic species, and frequency of oxygen deficiency (Mannio et al., 2000; Dodson et al., 2005; Vuori et al., 2006). All these may have impact on $\mathrm{CH}_{4}$ production and oxidation conditions, and cause variability observed in $\mathrm{CH}_{4}$ concentrations.

\subsection{Methane concentrations}

Average $\mathrm{CH}_{4}$ concentrations in the surface waters in the current study, $0.2-1.8 \mu \mathrm{mol} \mathrm{L}^{-1}$ (Table 3) were comparable to average surface water concentration of $\mathrm{CH}_{4}$ in 13 oligotrophic Swedish lakes of $0.1-1.9 \mu \mathrm{mol} \mathrm{L}^{-1}$ and in $11 \mathrm{Wis}-$ consin lakes of $0.3-2.3 \mu \mathrm{mol} \mathrm{L}^{-1}$ (Bastviken et al., 2004). The highest dissolved $\mathrm{CH}_{4}$ concentrations measured close to the sediment in our study were similar with, for example, those reported for the eutrophic Lakes 277 and Wintergreen (Rudd and Hamilton, 1978; Strayer and Tiedje, 1978). According to our data, the key variables associated with variation in lake water $\mathrm{CH}_{4}$ concentration are oxygen saturation, nutrient status implying productivity, lake area and depth, which is in line with studies of Michmerhuizen et al. (1998); Huttunen et al. (2003), and Bastviken et al. (2004).

Poor oxygen saturation and high nutrient status predict high $\mathrm{CH}_{4}$ concentration in the bottom water (Fig. 3, Table 4). These factors indicate a condition favoring higher $\mathrm{CH}_{4}$ production rates and hindering $\mathrm{CH}_{4}$ oxidation (e.g. Rudd and Hamilton, 1978; Huttunen et al., 2003). In addition, bottom $\mathrm{CH}_{4}$ concentration was positively yet weakly related with TOC and water temperature, but this can be also due to the southern distribution of most productive and humic lakes, and strong stratification and oxygen consumption rates in humic lakes (Bastviken et al., 2004, Kankaala et al., 2007). The negative correlation between area-to-depth ratio (considered small for a deep lake with small area) and $\mathrm{CH}_{4}$ concentration suggest that wind driven water column mixing can keep bottom water $\mathrm{CH}_{4}$ concentration low during open water season. The summer bottom water $\mathrm{CH}_{4}$ examined against the lake types pointed that $\mathrm{CH}_{4}$ accumulation is likely when there is a risk of oxygen deficiency (Fig. 2): e.g. in deep lakes, nutrient rich lakes and in very humic lakes having strong stratification (Riera et al., 1999; Huttunen et al., 2002a; Bastviken et al., 2004; Kankaala et al., 2007). In winter $\mathrm{CH}_{4}$ accumulation is likely in shallow lakes due to small water volume and, thereafter, small oxygen storage.

The $\mathrm{CH}_{4}$ concentrations in bottom-close water during winter were significantly higher in lakes having frequently anoxic bottom water and highest Ptot levels than in lakes having lower Ptot levels or less frequent anoxia (Fig. 4, Table 5).
Because of this connection among nutrient level, oxygen saturation and $\mathrm{CH}_{4}$, the amount of $\mathrm{CH}_{4}$ in the sediment close water might serve as a classification measure that integrates oxygen and nutrient status (cf. Huttunen et al. 2006). Anoxia and high nutrient levels are typically correlated due to oxygen consumption by decomposition and by nutrient release from the sediment in anoxic conditions. However, factors affecting the water column mixing and gas exchange, i.e depth and area (Fee et al., 1996) have an impact on lake oxygen status during the open water season too (Table 4).

Factors that are associated with the surface water $\mathrm{CH}_{4}$ concentration are significant since the surface water $\mathrm{CH}_{4}$ concentration is the driver of diffusive $\mathrm{CH}_{4}$ flux to the atmosphere. The surface water $\mathrm{CH}_{4}$ concentrations were typically the highest in shallow lakes both during the late winter and the late summer (Table 4, Figs. 2 and 3). Significant relationships between $\mathrm{CH}_{4}$ concentration and oxygen saturation, Ptot and TOC in winter indicate that during the ice cover the nutrient rich and humic shallow lakes tend to have proportionally large anoxic water volume, allowing $\mathrm{CH}_{4}$ accumulation at the water layers where oxygen deficiency hinders oxidation of $\mathrm{CH}_{4}$.

During the open water season, in turn, lake area and depth and their ratio affect, first, how much of the $\mathrm{CH}_{4}$ reaches the surface layer and, second, the loss of $\mathrm{CH}_{4}$ from lake surface to the atmosphere. In the shallow lakes the epilimnion and productive littoral sediments have a large contribution to the total sediment area and gas efflux to the water column. In the epilimnion the sedimentary gases are mixed to the surface layer, while the hypolimnion is isolated from the surface layer by stratification (den Heyer and Kalf, 1998; Bastviken et al., 2004; Murase et al., 2005; Bastviken et al., 2008). The shallow lakes may also maintain the high surface $\mathrm{CH}_{4}$ concentration due to lower gas exchange rates between the surface and the atmosphere, because these lakes likely have small area and are wind sheltered (cf. Bastviken et al., 2004). Correlation between bottom water and surface water concentrations was poor, which follows from the multiple processes in the sediment throughout the water column and water surface determining the $\mathrm{CH}_{4}$ concentration (Rudd and Hamilton, 1978; Bastviken et al. 2004; Kankaala et al., 2006, 2007). Besides, the surface water $\mathrm{CH}_{4}$ likely originates from different sediments than just below the sampling point due to the lateral mixing of the water (Bastviken et al., 2008).

Identifying the formation of $\mathrm{CH}_{4}$ storage in a lake is important, because $\mathrm{CH}_{4}$ storage can turn to large $\mathrm{CH}_{4}$ release. Eutrophic and humic lakes with substantial volume can be sites of big storage fluxes, but storage formation can be also common in smaller lakes due to their susceptibility to anoxia. The current study also shows that accumulation of $\mathrm{CH}_{4}$ storage during summer is comparable to $\mathrm{CH}_{4}$ accumulation during the ice covered season in many lakes of this region (Fig. 2). It has been shown that summer storage can make significant part of the annual $\mathrm{CH}_{4}$ release particularly in the humic lakes (Kankaala et al., 2007). 


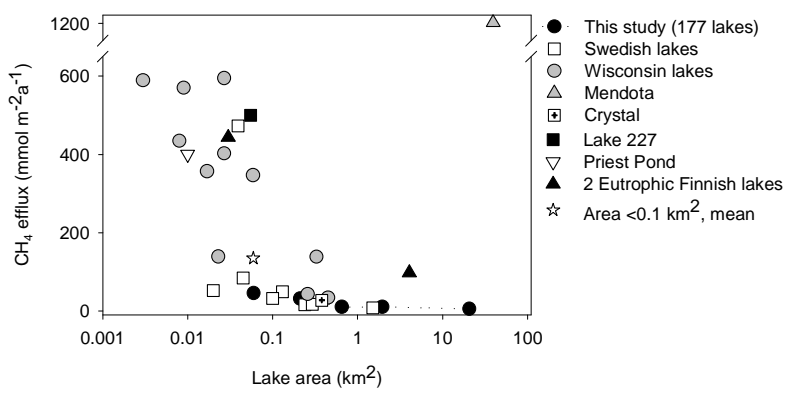

Fig. 7. Sum of the diffusive and storage fluxes in relation to lake surface area in the lakes of this study and some other studied lakes. Median $\mathrm{CH}_{4}$ values (black circles) are plotted against median lake size in the size classes $<0.1,0.1-<0.5,0.5-1,1-<10,10-<100$, and $>100 \mathrm{~km}^{2}$ for the lakes of statistic sample of our study. Estimates of $\mathrm{CH}_{4}$ release (diffusion and storage fluxes) from some other lakes studied by Rudd and Hamilton (1978), Fallon et al. (1980), Michmerhuizen et al. (1998), Casper et al. (2000), Huttunen et al. (2003) and Bastviken et al. (2004, Table 1) are plotted for a comparison.

\subsection{Diffusive and storage fluxes to the atmosphere}

Two flux components, $\mathrm{CH}_{4}$ diffusion from the surface during the open water season and the release of accumulated $\mathrm{CH}_{4}$ storage during the over turn periods, were estimated on the basis of the concentration data. These estimates provide only a partial fraction of annual $\mathrm{CH}_{4}$ release from the lakes, because ebullition and plant-mediated fluxes are not included. The uncertainty in our flux estimates follows from assumptions concerning the use of concentration data and boundary layer models, and those of horizontal and vertical scaling up over the whole lake. A constant wind speed value was used to estimate diffusive flux, which thus might be overestimated for the small and sheltered lakes while underestimated for the larger lakes where the surface is more exposed to wind (see Bastviken et al., 2004). The boundary layer diffusion model often gives values lower than chamber measurements, another method to estimate fluxes, yet not in a consistent manner (Phelps et al., 1998; Duchemin et al., 1999; Kankaala et al., 2006; Repo et al., 2007).

Another part of our budget is based on the assumption that the difference between the before and after turnover storage terms is released to the atmosphere, but part of the difference can be due to $\mathrm{CH}_{4}$ oxidation. For example, in Lakes 227, Williams and Kevätön oxidation consumed a small proportion of $\mathrm{CH}_{4}$ in the water body during the spring overturn. Methane consumption was larger in relatively shallow L. Kevätön, and $60-80 \%$ of the pre-overturn $\mathrm{CH}_{4}$ storage was oxidized in deeper Lake 227 and meromictic Mekkojarvi in autumn (Rudd and Hamilton, 1978; Michmerhuizen et al., 1996; Liikanen et al., 2002; Kankaala et al., 2007).

Ebullition may dominate $\mathrm{CH}_{4}$ flux in many of the nutrientrich and shallow lakes in our study (Huttunen et al., 2003; Bastviken et al., 2004). Thus, concentration data alone give a biased indication of $\mathrm{CH}_{4}$ emissions and, moreover,
$\mathrm{CH}_{4}$ released in bubbles may cause some problems to predict variation in observed concentration data. In addition, the vegetated and very shallow littoral areas fall outside of this estimation. They might have much higher $\mathrm{CH}_{4}$ emissions than predicted on the basis of $\mathrm{CH}_{4}$ concentration in the pelagic zone (Smith and Lewis, 1992; Juutinen et al., 2003; Bergström et al., 2007). Although water layers are assumed to be horizontally mixed, sometimes horizontal concentration gradients have been identified. Those can be caused by $\mathrm{CH}_{4}$ inputs from littoral sediments, adjacent peatlands, or incoming streams (Schmidt and Conrad, 1993; Larmola et al., 2004; Murase et al., 2005; Repo et al., 2007; Bastviken et al., 2008). Moreover, Some uncertainty related to volume estimates and vertical and horizontal extrapolation based on four concentration measures is evident.

Median flux value for the 177 statistically selected lakes is $21 \mathrm{mmol} \mathrm{m}^{-2} \mathrm{a}^{-1}$ (Fig. 5). The average value for these lakes, $49 \mathrm{mmol} \mathrm{m}^{-2} \mathrm{a}^{-1}$, is close to the average estimate of $41 \mathrm{mmol} \mathrm{m}^{-2} \mathrm{a}^{-1}$ for 8 Swedish lakes including the same flux components (Bastviken et al., 2004). The estimates are generally similar within the same lake size range (Fig. 7). In addition, $\mathrm{CH}_{4}$ flux estimates with the same flux components for some Wisconsin lakes (Michmerhuizen et al., 1998; Bastviken et al., 2005) are comparable and show similar relation to the lake size within the same lake size range. The sum of diffusion and storage components for the smaller Wisconsin lakes, in turn, were much higher than the flux estimates of our study. The difference could be partly related to the smaller size, implying the large sediment area-to-volume ratio. In addition, the more continental climate and quick warm up of those lakes leading to longer stratification period and thus larger storage flux of $\mathrm{CH}_{4}$. Those lakes had also warmer sediments than the Swedish - and presumably other more northern - lakes (Bastviken et al., 2004). Eutrophic lakes, for example a hypereutrophic Finnish lake, L. Kevätön, had higher $\mathrm{CH}_{4}$ emissions (Fig. 7) (Huttunen et al., 2003).

The explanatory power of the predictive models for $\mathrm{CH}_{4}$ fluxes remained rather low, but our data indicates that productivity, oxygen saturation, and factors associated to the gas transport from sediments to the water column and to the atmosphere largely determine the estimated sum of storage and diffusion flux. The lake area or depth seems to integrate much of these factors among the studied lakes (Figs. 5, 6, 7, Table 7). Bastviken et al. (2004) concluded that $\mathrm{CH}_{4}$ fluxes can be predicted on the basis of total phosphorus, DOC, and methane concentrations, and that ebullition is dependent on water depth. Michmerhuizen et al. (1998) connected small area with the highest storage fluxes. In small and shallow lakes, sediments, where methanogenesis take place, are in touch with large water volume. In addition, probability of substantial littoral contribution, i.e. macrophyte and microphyte production and input of organic matter to the system, is considerable. Small water volume when associated with high organic matter content is susceptible to formation of anoxic conditions favoring $\mathrm{CH}_{4}$ accumulation. 
Overall, humic and nutrient-rich lakes, which had higher $\mathrm{CH}_{4}$ fluxes than the clear and oligotrophic lakes, were common among the small lakes resulting in higher concentrations and fluxes of $\mathrm{CH}_{4}$ fluxes in small lakes than in larger lakes. Climate and topography of the study region may thus affect our conclusion that lake area could be a simple scaling up tool (Fig. 7). However, factors determining productivity and susceptibility to anoxia should be included to the predictive models of $\mathrm{CH}_{4}$ fluxes. The climatic effect on the $\mathrm{CH}_{4}$ fluxes within this geographical gradient was negligible, but a longer climatic gradient might include greater differences in productivity and also in $\mathrm{CH}_{4}$. The weak regression coefficient in the model for spring storage might be due to the influence of the length of the ice cover period to the storage formation.

\subsection{Global $\mathrm{CH}_{4}$ flux}

Estimate of global $\mathrm{CH}_{4}$ flux based on these data is $3.7 \mathrm{Tg} \mathrm{a}^{-1}$. It is based on $\mathrm{CH}_{4}$ flux values for different size classes and the recent estimates of total lake area in each size class (Downing et al., 2006). Methane values come from the statistic sample of 177 lakes in our study, but for lakes having size $<0.1 \mathrm{~km}^{2}$, we calculated mean $\left(135 \mathrm{mmol} \mathrm{m}^{-2} \mathrm{a}^{-1}\right)$ using data from 55 lakes in our study and data from some other lakes (see Fig. 7, Rudd and Hamilton, 1978; Bastviken et al., 2004).

This estimate is smaller than the recent estimates, which range from 8 to $48 \mathrm{Tg} \mathrm{a}^{-1}$ and include ebullition (Bastviken et al., 2006; Walter et al., 2007). Ebullition and fluxes from vegetated littoral zone are worth of recognition, because those may contribute more than the sum of storage and diffusion fluxes to the lake wide fluxes (Smith and Lewis, 1992; Huttunen et al., 2003; Juutinen et al., 2003; Bastviken et al., 2004; Bersgtröm et al. 2007; Walter et al., 2007). Assuming that each flux component has an equal contribution, and thus multiplying the estimate by three, it (about $10 \mathrm{Tg} \mathrm{a}^{-1}$ ) would overlap the lower end of the previous estimates. Our data is representative for the boreal zone, i.e. for a large number of lakes, but it is unclear whether global $\mathrm{CH}_{4}$ emission estimate would be affected by southern lakes possibly having different conditions and $\mathrm{CH}_{4}$ emissions.

\section{Conclusions}

The current study focused on small northern lakes, where lake size tended to be a strong predictor of methane concentrations and fluxes. Lake size, i.e. depth or area, seems to integrate the combination of factors driving $\mathrm{CH}_{4}$ concentration dynamics, but knowledge on lake nutrient and oxygen status would improve the estimation. The other way round, $\mathrm{CH}_{4}$ concentration in bottom close water could serve as a measure of excess nutrients and occurrence of anoxia when doing environmental monitoring of lakes. In the absence of more accurate data, lake area from remote surveys could be used as an approximation for the $\mathrm{CH}_{4}$ emissions in boreal and arctic landscapes with similar glacial history. Small lakes seem to have a disproportionate significance with respect to $\mathrm{CH}_{4}$ release, even if large lakes dominate regional emission estimates in absolute numbers. Our study support earlier lake studies on $\mathrm{CH}_{4}$ dynamics regarding to regulating factors and also the magnitude of global $\mathrm{CH}_{4}$ emission estimate.

Acknowledgements. This work is dedicated to the memory of our dear colleague and co-author Jari Huttunen who suddenly passed away during the final stages of the project. We also acknowledge David Bastviken and an anonymous reviewer for valuable suggestions to improve this manuscript. Riitta Niinioja from Finnish Environment Institute (Joensuu) is thanked for the discussions and help with Finnish lake typology procedure. This study was funded by the Finnish Academy, and we acknowledge the personal grants to S. Juutinen (no. 213012) and to T. Larmola (no. 121353).

Edited by: T. J. Battin

\section{References}

Bastviken, D., Ejlertsson, J., and Tranvik, L.: Measurement of methane oxidation in lakes: A comparison of methods, Env. Sci. Tech. 36, 3354-3361, 2002.

Bastviken, D., Cole, J., Pace, M., and Tranvik, L.: Methane emissions from lakes: Dependence of lake characteristics, two regional assessments, and a global estimate, Glob. Biogeochem. Cycles, 18, GB4009, doi:10.1029/2004GB002238, 2004.

Bastviken, D., Cole J. J., Pace, M., and Van de Bogert, M. C.: Fates of methane from different lake habitats: Connecting whole-lake budgets and $\mathrm{CH}_{4}$ emissions, J. Geophys. Res., 113, G02024, doi:10.1029/2007JG00068, 2008.

Bergström, I., Mäkelä, S., Kankaala, P., and Kortelainen, P.: Methane efflux from littoral vegetation stands of southern boreal lakes: and upscaled, regional estimate, Atmos. Environ., 41, 339-351, 2007.

Chanton, J. P., Martens, C. S., and Kelley, C. A.: Gas transport from methane saturated, tidal freshwater and wetland sediments, Limnol. Oceanogr., 34, 807-819, 1989.

Cole, J. J. and Caraco, N. F.: Atmospheric exchange of carbon dioxide in a low-wind oligotrophic lake measured by the addition of $\mathrm{SF}_{6}$, Limnol. Oceanogr., 43, 647-656, 1998.

Cole, J. J., Prairie, Y. T., Caraco, N. F., McDowell, W. H., Tranvik, L. J., Striegl, R. G., Duarte, C. M., Kortelainen, P., Downing, J. A., Middelburg, J. J., and Melack, J.: Plumbing the global carbon cycle: Integrating inland waters into the terrestrial carbon budget, Ecosystems,10, 171-184, doi:10.1007/s10021-006-9013-8, 2007.

Dacey, J. W. H. and Klug, M. J.: Methane efflux from lake sediments through water lilies, Science, 203, 1253-1254, 1979.

den Heyer, C. and Kalff, J.: Organic matter mineralization rates in sediments: A within- and among-lake study, Limnol. Oceanogr., 43, 695-705, 1998.

Directive 2000/30/EC of the European Parliament and the council of 23 October 2000 establishing a framework for community action in the field of water policy, Official Journal of the European Communities L327, 1-72. 
Dodson, S. I., Lillie, R. A., and Will-Wolf, S.: Land use, water chemistry, aquatic vegetation, and zooplankton community structure of shallow lakes, Ecol. Appl., 15, 1191-1198, 2005.

Downing, J. A., Prairie, Y. T., Cole, J. J., Duarte, C. M., Tranvik, L. J., Striegl, R. G., McDowel, W. H., Kortelainen, P., Caraco, N. F., Melack, K. J. M., and Middelburg, J. J.: The global abundance and size distribution of lakes, ponds, and impoundments, Limnol. Oceanogr., 51, 2388-2397, 2006.

Duchemin, E., Lucotte, M., and Canuel, R.: Comparison of static chamber and thin boundary layer equation methods for measuring greenhouse gas emissions from large water bodies, Environ. Sci. Tech., 33, 350-357, 1999.

Fee, E. J., Hecky, R. E., Kasian, S. E. M., and Cruikshank, D. R.: Effects of lake size, water clarity, and climatic variability on mixing depths in Canadian Shield lakes, Limnol. Oceanogr., 41, 912-920, 1996.

Finnish Meteorological Institute: Meteorological yearbook of Finland, 1998, 78 pp., 1999, (in Finnish).

Finnish Meteorological Institute: Meteorological yearbook of Finland, 1999, 78 pp., 2000, (in Finnish).

Hamilton, J. D., Kelly, C. A., Rudd, J. W. M., Heslein, R. H., and Roulet, N. T.: Flux to the atmosphere of $\mathrm{CH}_{4}$ and $\mathrm{CO}_{2}$ from wetland ponds on the Hudson Bay Lowlands (HBLs), J. Geophys. Res., 99(D1), 1495-1510, 1994.

Huttunen, J. T., Väisänen, T., Heikkinen, M., Hellsten, S., Nykänen, H., Nenonen, O., and Martikainen, P. J.: Exchange of $\mathrm{CO}_{2}, \mathrm{CH}_{4}$ and $\mathrm{N}_{2} \mathrm{O}$ between the atmosphere and two northern boreal ponds with catchments dominated by peatlands or forests, Plant. Soil, 242, 137-146, 2002.

Huttunen, J. T., Alm, J., Liikanen, A., Juutinen, S., Larmola, T., Hammar, T., Silvola, J., and Martikainen, P. J.: Fluxes of methane, carbon dioxide and nitrous oxide in boreal lakes and potential anthropogenic effects on the aquatic greenhouse gas emissions, Chemosphere, 52, 609-621, 2003.

Huttunen, J. T., Väisänen, T. S., Hellsten, S. K., and Martikainen, P. J.: Methane fluxes at the sediment - water interface in some boreal lakes and reservoirs, Bor. Env. Res., 11, 27-34, 2006.

Hyvärinen, V. and Korhonen, J.: Hydrological Yearbook 19962000, The Finnish Environment, 599, 219 pp., Finnish Environment Institute, Helsinki, 2003, (in Finnish).

Jähne, B., Münnich, K. O., Bösinger, R., Dutzi, A., Huber, W., and Libner, P.: On the parameters influencing air-water gas exchange, J. Geophys. Res., 92, 1937-1949, 1987.

Juutinen, S., Alm, J., Larmola, T., Huttunen, J.T., Morero, M., Martikainen, P. J., and Silvola, J.: Major implication of the littoral zone for methane release from boreal lakes, Glob. Biogeochem. Cycles, 17(4), 1117, doi:10.1029/2003GB002105, 2003.

Kankaala, P., Huotari, J., Peltomaa, E., Saloranta, T., and Ojala, A.: Methanotrophic activity in relation to methane efflux and total heterotrophic bacterial production in a stratified, humic, boreal lake, Limnol. Oceanogr., 51, 1195-1204, 2006.

Kankaala, P., Taipale, S., Nykänen, H., and Jones, R. I.: Oxidation, efflux, and isotopic fractionation of methane during autumnal turnover in a polyhumic, boreal lake, J. Geophys. Res., 112, Go2003, doi:10/1029/2006JG000336, 2007.

Kelly, C. A. and Chynoweth, D. P.: The contributions of temperature and of the input of organic matter in controlling rates of sediment methanogenesis, Limnol. Oceanogr., 26, 891-897, 1981.

Kortelainen, P., Huttunen, J., Väisänen, T., Mattsson, T., Kar- jalainen, P., and Martikainen, P.J.: $\mathrm{CH}_{4}, \mathrm{CO}_{2}$ and $\mathrm{N}_{2} \mathrm{O}$ supersaturation in 12 Finnish lakes before and after ice melt, Verh. Int. Ver. Limnol., 27, 1410-1414, 2000.

Kortelainen, P., Pajunen, H., Rantakari, M., and Saarnisto, M.: A large carbon pool and small sink in boreal Holocene lake sediments, Global Change Biol., 10, 1648-1653, 2004.

Kortelainen, P., Rantakari, M., Huttunen, J.T., Mattson, T., Alm, J., Juutinen, S., Larmola, T., Silvola, J., and Martikainen, P. J.: Sediment respiration and lake trophic state are important predictors of large $\mathrm{CO}_{2}$ evasion from small boreal lakes, Glob. Change Biol., 12, 1554-1567, 2006.

Larmola, T., Alm, J., Juutinen, S., Huttunen, J. T., Martikainen, P. J., and Silvola, J.: Contribution of vegetated littoral zone to winter fluxes of carbon dioxide and methane from boreal lakes, J. Geophys. Res., 109, D19102, doi:10.1029/2004JD004875, 2004.

Lide, D. R. and Fredrikse, H. P. R.: CRC Handbook of Chemistry and Physics, 76th ed., CRC Press, Boca Raton, Fla, 1995.

Liikanen, A., Huttunen, J. T., Murtoniemi, T., Tanskanen, H., Väisänen, T., Silvola, J., Alm, J., and Martikainen, P. J.: Spatial and seasonal variation in greenhouse gas and nutrient dynamics and their interactions in the sediments of a boreal eutrophic lake, Biogeochemistry, 65, 83-103, 2003.

Liikanen, A., Huttunen, J.T., Valli, K., and Martikainen, P. J.: Methane cycling in the sediment and water column of mid-boreal hyper-eutrophic lake Kevätön, Arch. Hydrobiol., 154, 585-603, 2002.

MacIntyre, S., Wanninkof, R., and Chanton, J. P.: Trace gas exchange across the air-water interface in freshwater and coastal marine environments, in , edited by: Matson, P. A. and Harriss, R. C., Biogenic trace gases: Measuring emissions from soil and water. Methods in ecology, 52-97, Blackwell Science, 1995.

Mannio, J., Räike, A., and Vuorenmaa, J.: Finnish lake survey 1995: regional characteristics of lake chemistry, Verh. Internat. Verein. Limnol., 27, 362-367, 2000.

McAuliffe, C. C.: GC determination of solutes by multiple phase equilibration, Chem. Technol., 1, 46-51, 1971.

Michmerhuizen, C. M., Striegl, R. G., and McDonald, M. E.: Potential methane emission from north-temperate lakes following ice melt, Limnol. Oceanog., 41, 985-991, 1996.

Murase, J., Sakai, Y., Kametani, A., and Sugimoto, A.: Dynamics of methane in mesotrophic Lake Biwa, Japan, Ecol. Res., 20, 377-385, 2005.

National Board of Waters: Methods of water analysis employed by the Water Administration, Helsinki, 136 pp. National Board of Waters, Finland, 1981.

Phelps, A. R., Peterson, K. M., and Jeffries, M. O.: Methane efflux from high-latitude lakes during spring ice melt, J. Geophys. Res., 103, 29029-29030, 1998.

Rantakari, M., Kortelainen, P., Vuorenmaa, J., Mannio, J., and Forsius, M.: Finnish lake survey: the role of catchment attributes in determining nitrogen, phosphorous and organic carbon concentrations, Water Air Soil Poll. Focus, 4, 683-399, 2004.

Rantakari, M. and Kortelainen, P.: Interannual variation and climatic regulation of the $\mathrm{CO}_{2}$ emission from large boreal lakes, Glob. Change Biol., 11, 1368-1380, 2005.

Repo, M. E., Huttunen, J. T., Naumov, A. V., Chichulin, A. V., Lapshina, E. D., Bleuten, W., and Martikainen, P. J.: Release of $\mathrm{CO}_{2}$ and $\mathrm{CH}_{4}$ from small wetland lakes in western Siberia, Tellus, 59, 788-796, doi:10.1111/j.1600-0889.2007.00301.x, 2007. 
Riera, J. L., Schindler, J. E., and Kratz, T. K.: Seasonal dynamics of carbon dioxide and methane in two clear-water lakes and two bog lakes in northern Wisconsin, USA, Can. J. Fish. Aquat. Sci., 56, 265-274, 1999.

Rudd, J. M. W. and Hamilton, R. D.: Methane cycling in a eutrophic shield lake and its effects on whole lake metabolism, Limnol. Oceanogr., 23, 337-349, 1978.

Saarnio, S., Winiwater, W., and Leitão, J.: Methane release from wetlands and watercourses in Europe, Atm. Env., 43, 1421-1429, doi:10.1016/j.atmosenv.2008.04.007, 2009.

Schmidt, U. and Conrad, R.: Hydrogen, carbon monoxide, and methane dynamics in Lake Constance, Limnol. Oceanogr., 38, 1214-1226, 1993.

Smith, L. K. and Lewis, M. W.: Seasonality of methane emissions from five lakes and associated wetlands of the Colorado Rockies, Glob. Biogeochem. Cycles, 6, 323-338, 1992.

Smith, L. C., Sheng, Y., MacDonald, G. M., and Hinzman, L. D.: Disappearing arctic lakes, Science, 308, 1429, doi:10.1126/Science.1108142, 2005.

Smol, J. P. and Douglas, M. S. V.: Crossing the final ecological threshold in high Arctic ponds, Proc. Nat. Acad. Sci., 104, 12395-12397, 2007.
Sorrano, P. A., Cheruvelil, K. S., Stevenson, R. J., Rollins, S. L., Holden, S. W., Heaton, S., and Torgn, E.: A framework for developing ecosystem-specific nutrient criteria: Integrating biological thresholds with predictive modeling, Limnol. Oceanogr., 53, 773-787, 2008.

Strayer, R. F. and Tiedje, J. M.: In situ methane production in small, hypereutrophic, hard-water lake: Loss of methane from sediments by vertical diffusion and ebullition, Limnol. Oceangr., 23, 1201-1206, 1978.

Walter, K. M., Smith, L. C., and Chapin III, F. S.: Methane bubbling from northern lakes: present and future contributions to the global methane budget, Phil. Trans. Royal Soc., 365, 1657-1676, 2007.

Vuori, K. M., Bäck, S., Hellsten, S., Karjalainen, S. M., Kauppila, P., Lax, H.-G., Lepistö, L., Londesborough, S., Mitikka, S., Niemelä, P., Niemi, J., Perus, J., Pietiäinen, O.-P., Pilke, A., Riihimäki, J., Rissanen, J., Tami, J., Tolonen, K., Vehanen, T., Vuoristo, H., and Westerberg, V.: The basis for typology and ecological classification of water bodies in Finland, The Finnish Environment 807, 151 pp., Finnish Environment Institute (SYKE), 2006, (in Finnish with English abstract). 